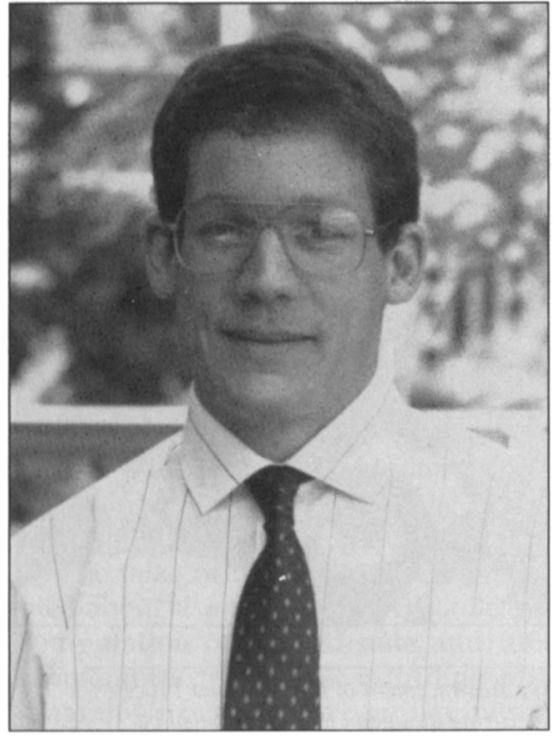

Charles Lieber

Charles Lieber, a professor at Harvard University, is the 1993 recipient of the Materials Research Society's Outstanding Young Investigator Award for "exceptional initiative, leadership, and accomplishment in materials research, with pioneering contributions to the understanding of novel materials through synthesis and elegant determination of complex local structure and electronic properties."

Lieber has made many significant contributions to the understanding of complex materials, among them layered metal dichalcogenides, high-temperature superconductors, donor-acceptor inorganic complexes, and doped fullerenes. He works closely with theoretical physicists to define appropriate problems to pursue, and is eager to interact with people in disciplines outside his own specialty of chemistry. His synthetic chemistry expertise allows him to test specific theoretically made predictions.

Lieber used solid-state synthesis to prepare metal-atom-doped $\mathrm{TaS}_{2}$ and used STM to visualize the resulting local perturbations to the electronic structure, giving the first direct view of the charge density wave domains in this material.

$\mathrm{He}$ also used solid-state synthesis to prepare metal-substituted high-temperature superconductors and investigated the structural and electronic effects of substitution at the atomic level by STM. Lieber elucidated the controversial structural questions in $\mathrm{Pb}$-substituted $\mathrm{Bi}$ based materials by showing the specif-

\section{Lieber Receives 1993 Outstanding Young Investigator Award}

\author{
"For exceptional initiative, leadership, \\ and accomplishment in materials \\ research, with pioneering \\ contributions to the understanding \\ of novel materials through synthesis \\ and elegant determination of \\ complex local structure and \\ electronic properties."
}

icity of electron-state perturbation by $\mathrm{Pb}$ incorporation-results that suggest new substitutions that might further increase $\mathrm{T}_{c}$ in these systems. He also used chemical doping to introduce controlled defects into the Bi-based materials and demonstrated how these defects increased the critical current density in the materials more than one order of magnitude. He defined the magnitude and temperature dependence of the superconducting energy gap in $\mathrm{BiSrCaCuO}$, using high-resolution electron energy loss spectroscopy (HREELS).

More recently, Lieber carried out incisive experiments that illuminated the

\section{MRS Outstanding Young Investigator Award}

Purpose: To recognize outstanding, interdisciplinary scientific work in materials research by a young scientist or engineer. The awardee must also show exceptional promise as a developing leader in the materials area.

Nomination deadline for the 1994 Award is October 1, 1993.

For information about eligibility and nomination procedures, contact: Anne Wagner (OYI-B), Materials Research Society, 9800 McKnight Road, Pittsburgh, PA 15237; phone (412) 367-3003; fax (412) 367-4373 mechanism of superconductivity in metal doped fullerenes. His detailed tunneling spectroscopy measurements defined the energy scale for pair-binding in the fullerene superconductors. He also developed a synthetic technique to prepare well-defined ${ }^{13} \mathrm{C}$ substituted fullerenes, and used these materials to define the isotope effect on superconductivity.

Lieber earned his BA degree in chemistry from Franklin and Marshall College in 1981. In 1985, he received his PhD degree in chemistry from Stanford University, having done research on photoelectrochemistry. He performed postdoctoral research on photoinduced electron transfer reactions at the California Institute of Technology until 1987, when he joined Columbia University as assistant professor of chemistry. He became an associate professor in 1990. At Columbia, Lieber created a new field of structural inorganic chemistry which combines solid-state synthesis and scanning tunneling microscopy (STM). In 1991, he became a full professor of chemistry at Harvard University.

Lieber has more than 60 publications to his name. Among his awards are the 1992 American Chemical Society Pure Chemistry Award, the 1992 Kinkewalter Prize, and a Presidential Young Investigator Award for the years 1988-1993. Lieber is a member of the American Chemical Society, the American Physics Society, the American Association for the Advancement of Science, and the Materials Research Society. 


\section{SPRING MEETING SYMPOSIUM PROCEEDINGS}

Place your order now for proceedings from the 1993 MRS Spring Meeting in San Francisco. You'll receive your books as soon as they are published.

A: Amorphous Silicon Technology - 1993

Editors: E.A. Schiff, M.J. Thompson,

P.G. LeComber, A. Madan, K. Tanaka

ISBN: 1-55899-193-X Code: 297-B

$\$ 65$ MRS Members

$\$ 75$ U.S. List

$\$ 80$ Foreign

B: Silicon-Based Optoelectronic Materials Editors: R.T. Collins, M.A. Tischler,

G. Abstreiter, M.L. Thewalt

ISBN: 1-55899-194-8 Code: 298-B

$\$ 55$ MRS Members

\$65 U.S. List

$\$ 70$ Foreign

C2: Infrared Detectors - Materials,

Processing, and Devices

Editors: A. Appelbaum, L.R. Dawson

ISBN: 1-55899-195-6 Code: 299-B

$\$ 50$ MRS Members

$\$ 60$ U.S. List

$\$ 65$ Foreign

D1: III-V Electronic and Photonic Device Fabrication and Performance

Editors: K.S. Jones, S.J. Pearton, H. Kanber

ISBN: 1-55899-196-4 Code: 300-B

$\$ 55$ MRS Members

$\$ 65$ U.S. List

$\$ 70$ Foreign

E: Rare-Earth Doped Semiconductors

Editors: G.S. Pomrenke, P.B. Klein,

D.W. Langer

ISBN: 1-55899-197-2 Code: 301-B

$\$ 55$ MRS Members

$\$ 65$ U.S. List

$\$ 70$ Foreign

F: Semiconductors for Room-Temperature

Radiation Detector Applications

Editors: R.B. James, P. Siffert,

T.E. Schlesinger, L. Franks

ISBN: 1-55899-198-0 Code: 302-B

$\$ 57$ MRS Members

$\$ 67$ U.S. List

$\$ 72$ Foreign

G: Rapid Thermal and Integrated

Processing II

Editors: J.C. Gelpey, J.K. Elliott,

J.J. Wortman, A. Ajmera

ISBN: 1-55899-199-9

Code: $303-B$

$\$ 55$ MRS Members

$\$ 65$ U.S. List

$\$ 70$ Foreign
H: Polymer/Inorganic Interfaces

Editors: R.L. Opila, A.W. Czanderna,

F. J. Boerio

ISBN: 1-55899-200-6 Code: 304-B

$\$ 53$ MRS Members

$\$ 63$ U.S. List

\$68 Foreign

I: High-Performance Polymers and Polymer Matrix Composites

Editors: R.K. Eby, R.C. Evers, D. Wilson,

M.A. Meador

ISBN: 1-55899-201-4 Code: 305-B

\$57 MRS Members

$\$ 67$ U.S. List

$\$ 72$ Foreign

K: Materials Aspects of X-Ray Lithography

Editors: G.K. Celler, J.R. Maldonado

ISBN: 1-55899-202-2 Code: 306-B

$\$ 62$ MRS Members

$\$ 72$ U.S. List

$\$ 77$ Foreign

L: Applications of Synchrotron Radiation

Techniques to Materials Science

Editors: D.L. Perry, R. Stockbauer, N. Shinn, K. D'Amico, L. Terminello

ISBN: 1-55899-203-0 Code: 307-B

$\$ 62$ MRS Members

$\$ 72$ U.S. List

$\$ 77$ Foreign

M1: Thin Films - Stresses and Mechanical

Properties IV

Editors: P.H. Townsend, J. Sanchez, C-Y. Li, T.P. Weihs

ISBN: 1-55899-204-9 Code: 308-B

$\$ 62$ MRS Members

$\$ 72$ U.S. List

$\$ 77$ Foreign

M2: Materials Reliability in

Microelectronics III

Editors: K. Rodbell, B. Filter, P. Ho, H. Frost

ISBN: 1-55899-205-7 Code: 309-B

$\$ 62$ MRS Members

$\$ 72$ U.S. List

$\$ 77$ Foreign

N: Ferroelectric Thin Films III

Editors: E.R. Myers, B.A. Tuttle, S.B. Desu, P.K. Larsen

ISBN: 1-55899-206-5 Code: 310-B

\$58 MRS Members

$\$ 68$ U.S. List

$\$ 73$ Foreign
O: Phase Transformations in Thin Films -

Thermodynamics and Kinetics

Editors: M. Atzmon, J.M.E. Harper,

A.L. Greer, M.R. Libera

ISBN: 1-55899-207-3

Code: $311-\mathrm{B}$

$\$ 62$ MRS Members

$\$ 72$ U.S. List

$\$ 77$ Foreign

P: Common Themes and Mechanisms of Epitaxial Growth

Editors: P. Fuoss, J. Tsao, D.W. Kisker,

A. Zangwill, T.F. Kuech

ISBN: 1-55899-208-1

Code: $312-B$

$\$ 62$ MRS Members

$\$ 72$ U.S. List

$\$ 77$ Foreign

Q1/Q2: Magnetic Ultrathin Films,

Multilayers and Surfaces/ Magnetic

Interfaces - Physics and Characterization

(2 Volume Set)

Editors: C. Chappert, R.F.C. Farrow,

B.T. Jonker, R. Clarke, P. Grünberg,

K.M. Krishnan, S. Tsunashima/

E.E. Marinero, T. Egami, C. Rau,

S.A. Chambers

ISBN: 1-55899-211-1

Code: $313-B$

$\$ 68$ MRS Members

$\$ 78$ U.S. List

$\$ 82$ Foreign

R: Joining and Adhesion of Advanced

Inorganic Materials

Editors: A.H. Carim, D.S. Schwartz,

R.S. Silberglitt, R.E. Loehman

ISBN: 1-55899-212-X

Code: 314-B

$\$ 53$ MRS Members

$\$ 63$ U.S. List

$\$ 68$ Foreign

Y: Surface Chemical Cleaning and Passivation for Semiconductor Processing Editors: G.S. Higashi, E.A. Irene, T. Ohmi ISBN: 1-55899-213-8

$\$ 58$ MRS Members

Code: $315-B$

$\$ 68$ U.S. List

$\$ 73$ Foreign

\begin{tabular}{|l} 
ORDER FROM \\
Materials Research Society \\
9800 McKnight Road \\
Pittsburgh, PA 15237 U.S.A. \\
(412) 367-3012; FAX (412) 367-4373 \\
IN EUROPE, AFRICA \& THE MIDDLE EAST: \\
Clarke Associates - Europe Ltd. \\
13a Small Street \\
Bristol BS1 1DE, England \\
0272 268864; FAX 0272 226437
\end{tabular}




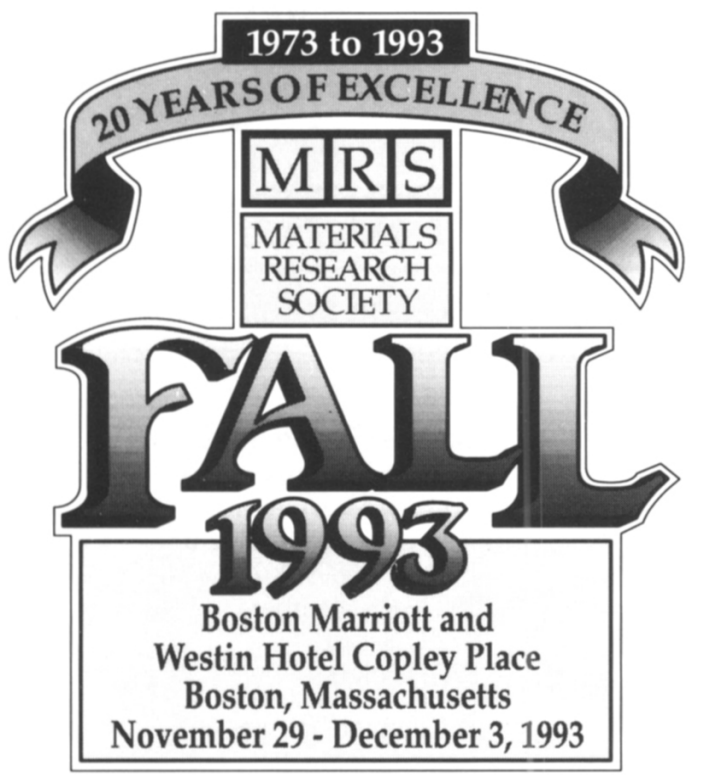

\section{TECHNICAL PROGRAM}

AA:Atomic Scale Imperfections in Materials - R.W. Balluffi Fest

A: Materials Synthesis and Processing Using Ion Beams

B: Mechanisms of Thin Film Evolution

Ca: Interface Control of Electrical, Chemical, and Mechanical Properties

Cb: Defect-Interface Interactions

D: Silicides, Germanides, and Their Interfaces

E: Crystallization and Related Phenomena in Amorphous Materials - Ceramics, Metals, Polymers, and Semiconductors

F: High-Temperature Silicides and Refractory Alloys

G: Fullerenes and Related Materials

H: Superconductivity - Materials and Properties

I: Developing Materials Processes for Factories

J: Electronic Packaging Materials Science VII

K: Diagnostic Techniques for Semiconductor Materials Processing

L: Defects in Advanced Semiconductors - Physics and Applications

M: Growth, Processing and Characterization of Semiconductor Heterostructures

$\mathrm{N}$ : Covalent Ceramics II: Non-Oxides

0: Complex Fluids

P: Disordered Materials - Fractals, Scaling, and Dynamics

Q: Electrical, Optical, and Magnetic Properties of Organic Solid State Materials

R: New Materials for Advanced Solid State Lasers

S: Biomolecular Materials by Design

T: Biomaterials for Drug and Cell Delivery

U: Determining Nanoscale Physical Properties of Materials by Microscopy and Spectroscopy

V: Scientific Basis for Nuclear Waste Management XVII

W: Gas-Phase and Surface Chemistry in Electronic Materials Processing

$\mathrm{X}$ : Frontiers of Materials Research

Y: Metal-Organic Chemical Vapor Deposition of Electronic Ceramics

\section{- New Materials Development - New Characterization Methods \\ - New Process Technology}

The 1993 Fall Program and Registration Materials book will be available in mid-September. If you would like a copy mailed to you, fax your request to: MRS 1993 Fall Program, (412) 367-4373.

\section{SHORT COURSE PROGRAM}

Courses on advanced materials characterization, preparation, and processing/diagnostic techniques have been designed for scientists, engineers, managers, and technical staff who wish to update their knowledge and skills in the research, development and processing of materials. These up-to-date courses are at the forefront of science and technology and complement Fall Meeting symposia. Class sizes are limited. Early preregistration is encouraged.

\section{EQUIPMENT EXHIBIT AND TABLE-TOP DISPLAY}

A major exhibit and table-top display of the latest analytical and processing equipment which closely parallels the nature of the technical symposia will be located in the Boston Marriott Hotel, convenient to the technical session rooms. For information, contact Merry Geil, Director of Meeting Activities, Materials Research Society, 9800 McKnight Road, Pittsburgh, PA 15237 • Telephone (412) 367-3003; Fax (412) 367-4373.

\section{PROCEEDINGS}

Many symposia from this meeting will publish proceedings. MRS members and meeting attendees may purchase copies of these proceedings at special prepublication prices and receive priority shipment upon publication. Prices will be higher following the meeting. To take advantage of these special prices, order your proceedings while registering for the meeting. For information on nonmember proceedings prices and ordering procedures, contact the MRS Publications Department.

\section{SYMPOSIUM AIDE OPPORTUNITIES}

By applying for Symposium Aide positions, graduate students who plan to attend the MRS 1993 Fall Meeting and are willing to assist in the symposium presentations can earn a waiver of the student registration fee, a one-year MRS student membership beginning January 1, 1994, and a stipend to help cover expenses.

\section{JOB PLACEMENT CENTER}

A Job Placement Center for MRS meeting and short course attendees will be open Tuesday through Thursday during the meeting adjacent to the Equipment Exhibit.

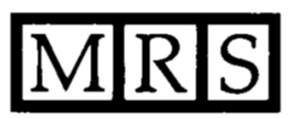

Materials Research Society

9800 McKnight Road, Pittsburgh, PA 15237-6006

Telephone (412) 367-3003 • Fax (412) 367-4373

The 1993 MRS Fall Meeting will serve as a key forum for discussion of interdisciplinary leading-edge materials research from around the world. Various meeting formats - oral, poster, roundtable, forum and workshop sessions - are offered to maximize participation. 